\title{
ОСНОВНЫЕ ПРОБЛЕМЫ СНИЖЕНИЯ УРОВНЯ ИННОВАЦИОННОЙ АКТИВНОСТИ В РЕГИОНАХ РОССИИ
}

\author{
Никонова М.А.
}

Снижение уровня инноваџионной активности в регионах России (особенно в наукоемких регионах) является до сих пор нерешенной и особенно актуальной проблемой. В статье рассмотрены основные проблемы, ведущие к спаду уровня инновачионной активности, среди которых можно выделить проблему качества подготовки научных кадров, нарушение преемственности в науке и низкую эффективность деятельности аспирантуры для сферы НИОКР, а также снижение патентной активности в наукоемких регионах России и низкую инвестиционную привлекательность инновационно активных регионов.

DOI: $10.20537 /$ mce2019econ05

Введение. В 1992-2017 гг. произошло значительное увеличение общей численности аспирантов (более чем в 2 раза) и численности аспирантов относительно численности кадров высшей квалификации $\left(\mathrm{KBK}^{*}\right)$, особенно в регионах с небольшим числом организаций, ведущих подготовку аспирантов, и невысокой численностью кадров высшей квалификации, что может быть свидетельством снижения качества подготовки научных кадров, особенно в регионах с невысоким числом организаций, ведущих подготовку аспирантов, и меньшей численностью КВК, где соотношение численности аспирантов и КВК выше, чем в наукоемких регионах (с большой численностью КВК и значительным числом организаций, ведущих подготовку аспирантов). Например, в Орловской, Смоленской и Брянской областях отношение численности аспирантов к численности КВК в 2017 г. составляло 380, 305, 438 аспирантов на 100 человек КВК, соответственно. В то же время в Москве, Московской, Новосибирской, Нижегородской и Калужской областях отношение численности аспирантов к численности КВК в 2014 г. составляло

\footnotetext{
* Лица, имеющие степень кандидата или доктора наук, т.е. те, кто потенциально имеет право научного руководства аспирантами.
} 
$65,25,49,83$ и 36 аспирантов на 100 человек КВК, соответственно (расчет по данным [1]).

Можно отметить, что в целом деятельность аспирантуры неэффективна для сферы НИОКР (об этом свидетельствует сопоставление динамики численности исследователей со степенью кандидата наук и численности выпуска из аспирантуры с защитой диссертации, которое показывает, что значительный рост численности аспирантов, закончивших аспирантуру с защитой диссертации, практически не отражается на притоке в науку исследователей со степенью кандидата наук). В абсолютных величинах численность исследователей со степенью кандидата наук за период 1993-2017 гг. сократилась практически на треть при росте численности выпуска из аспирантуры с защитой диссертации в 2015 г. в 3 раза (необходимо отметить, что после 2015 г. отмечается снижение числа выпуска из аспирантуры с защитой диссертации"). Неэффективность аспирантуры обостряет проблемы, связанные с преемственностью знаний. Проблемы воспроизводства научно-технических кадров в данной статье не рассматриваются (им посвящено довольно много внимания в статьях [2-5]).

Низкая доступность высшего образования также обостряет проблему преемственности знаний. Об этом свидетельствуют результаты специально проведенного обследования (среди ученых и преподавателей вузов), показавшие, что значительное расширение и высокая стоимость высшего образования на платной основе относительно средней заработной платы в экономике регионов снижает его доступность для большой части молодежи. Возможности оплатить обучение детей в вузах у представителей научно-образовательного сообщества весьма ограничены - верхняя планка возможностей в 2008 г. была равна 2000 долл. в год. Треть респондентов не могла найти 2000 долл. на оплату обучения своих детей ни при каких обстоятельствах. При годовой стоимости свыше 8000 долл. 99\% респондентов не могли оплатить обучение детей [6].

Высокая стоимость обучения отмечается, прежде всего, в наиболее престижных учебных заведениях, таких как МГУ, МГИМО и в ведущих региональных университетах. Проведенный анализ показал, что стоимость обучения в ведущих московских вузах в несколько раз превышает стоимость обучения в ведущих вузах Франции и Германии. Разрыв в

\footnotetext{
* Расчет по данным [1]
} 
стоимости обучения в региональных вузах России и зарубежных вузах меньше, но уровень жизни населения в регионах также ниже. Например, стоимость обучения в Ростовской государственной экономической академии примерно равна стоимости обучения в Мюнхенском техническом университете и в 2 раза выше стоимости обучения в Берлинском техническом университете, а превышение стоимости обучения в других российских вузах относительно стоимости обучения в указанных в таблице европейских вузах еще выше. С учетом того, что уровень среднедушевых денежных доходов во Франции и Германии выше уровня среднедушевых денежных доходов в регионах России, обучение в ведущих вузах (в том числе региональных) становится практически недоступным. Так, стоимость обучения в МГИМО для жителей Москвы составит $57 \%$ годового среднедушевого денежного дохода, в НИУ ВШЭ - $61 \%$, в Московском государственном техническом университете гражданской авиации $-25 \%$. Стоимость обучения в региональных вузах относительно среднедушевого денежного дохода в соответствующих регионах также высока: стоимость обучения в Южном федеральном университете составляет по некоторым специальностям 57\% среднедушевого денежного дохода, в Дальневосточном федеральном университете - $60 \%$. Стоимость обучения в вузах Франции или Германии значительно ниже годовая стоимость обучения в Сорбонне, Мюнхенском техническом университете или Берлинском техническом университете не превышает 6\% среднедушевого денежного дохода жителя Франции или Германии. Обучение во многих вузах России, в том числе в региональных вузах, при значительном сокращении бюджетных мест малодоступно для большей части населения. Это в долгосрочной перспективе может привести не только к еще большему усугублению проблемы преемственности в науке и последующему снижению инновационной активности регионов России, но и к снижению культурно-образовательного уровня населения России в долгосрочной перспективе.

Снижение патентной активности, особенно в инновационно активных регионах, является еще одним свидетельством снижения инновационной активности и, соответственно, замедления темпов инновационного развития стране. В среднем в России за период 2005-2017 гг. патентная активность не изменилась. В трети регионов наблюдалось снижение числа поданных заявок на изобретения и полезные модели. При этом среди 15 инновационно активных регионов (с числом поданных патентных заявок более 500 ед. в 2017 г.) падение патентной активности 
наблюдалось в 50 \% регионов (в том числе в Москве, Республике Татарстан, Нижегородской, Новосибирской, Самарской и Свердловской областях на 7\%, 2\%, 22.4\%, 7\%, 33.8\%, 22.2\%, соответственно).

Еще одной проблемой снижения инновационной активности является низкая привлекательность инновационно активных регионов для инвесторов, о чем свидетельствует отсутствие взаимного соответствия рейтингов инвестиционной привлекательности и инновационной активности для большинства регионов России.

Низкий интерес инвесторов к инновационно активным регионам (о чем свидетельствует отсутствие взаимного соответствия рейтингов инвестиционной привлекательности и инновационной активности для большинства регионов России) также является существенной проблемой снижения уровня инновационного развития страны. Анализ рейтингов инвестиционной привлекательности и инновационной активности регионов России показал, что первые места практически во всех рейтингах занимают Москва и Санкт-Петербург (исследовались следующие рейтинги: инвестиционные рейтинги: «Рейтинг регионов России по уровню инвестиционного потенциала» [7], «Рейтинг инвестиционной обеспеченности регионов России» [8]; инновационные рейтинги: «Рейтинг инновационных регионов России» [9], «Рейтинг регионов России по уровню инновационного развития» [10]). Остальные регионы, входящие в первую десятку инвестиционно привлекательных регионов, не всегда попадают в первую десятку инновационно активных регионов, и, наоборот, в первую десятку инновационно активных регионов попадают не самые инвестиционно привлекательные регионы. Например, Краснодарский и Красноярский край, Ленинградская, Ростовская, Самарская и Сахалинская области, Республика Коми, вошедшие в первую десятку инвестиционно привлекательных регионов, не попали в первые 10 инновационно активных регионов; и наоборот - Калужская, Томская, Ульяновская и Ярославская области, Чувашская Республика и Пермский край, являясь инновационно активными регионами, не входят в число регионов, представляющих интерес для инвесторов.

Таким образом, в статье были выделены основные проблемы инновационного развития страны. С начала 1990-х гг. произошло значительное сокращение сферы НИОКР России, особенно в регионах с высоким уровнем развития сферы НИОКР. При этом усугубилась проблема преемственности в сфере НИОКР, связанная с низкой доступностью высшего образования из-за его коммерциализации и неэффективностью 
аспирантуры для сферы НИОКР. При этом отмечающееся снижение патентной активности в наукоемких регионах и низкий интерес инвесторов к инновационно активным регионам замедляет переход экономики России к инновационному развитию.

\section{СПИСОК ЛИТЕРАТУРЫ}

1. «Регионы России. Социально-экономические показатели», 2003-2018 гг. Стат.сб. / Росстата России. М.; 2003-2018.

2. Кочеткова E.B. Современные проблемы удовлетворения спроса на инженерно-технические кадры (на примере США, Канады, стран Европы) // Haучно-практический журнал «Кониепции». № 31 (2). 2013. с. 56-66.

3. Дубинина М.Г. Занятость в сфере информационно-коммуникационных технологий в Европе: современные тенденции и профессиональные компетенции // Научно-практический журнал «Концепчии». № 33 (1). 2015. с. 55-67.

4. Яркин А.П. Обзор показателей развития научного потенциала России // Научно-практический журнал «Конщепщии». № 36 (1). 2017. с. 84-86.

5. Яркин А.П. Динамика показателей научного потенциала России // Научнопрактический журнал «Конщеепиии». № 34 (2). 2015. с. 77-79.

6. Винокурова Н.А., Никонова М.А. Коммерциализация высшего образования и его доступность // Математика. Компьютер. Образование: Сб. научных трудов. Том 2 / Под ред. Г. Ю. Ризниченко. - М.-Ижевск: НИЦ "Регулярная и хаотическая динамика". 2010. с. 84-91.

7. Рейтинги регионов по уровню инвестиционного потенциала и инвестиционного риска, разработанные агентством «Эксперт РА» URL: http://raexpert.ru/rankingtable/region_climat/2014/tab02/

8. Рейтинг регионов России по инвестиционной обеспеченности // Рейтинги, 2011. №1. c.10-12.

9. Рейтинг инновационных регионов России. URL: http://www.i-regions.org/reyting_innovations_regions.pdf

10. Рейтинг регионов России по уровню инновационного развития (ВШЭ) URL: http://gtmarket.ru/news/2014/03/13/6628 


\section{THE PROBLEMS OF REDUCING THE LEVEL OF INNOVATIVE ACTIVITY IN RUSSIAN REGIONS}

\section{Nikonova M.A.}

The decrease in the level of innovation activity in the Russian regions (especially in science-intensive regions) is still unresolved and particularly urgent problem. The article deals with the main problems of reducing innovation activity, among which are the decrease in the quality of training of scientific personnel, breakdown in science knowledge continuity together with low efficiency of postgraduate traineeship, as well as a decrease in patent activity in scienceintensive regions of Russia and low investment attractiveness of innovation-active regions. 